口特 集 $<$ 言語発達障害への言語・認知科学的アプローチ $>$

\title{
自閉症児における前言語的伝達行動の成立条件
}

\author{
山本 淳一
}

\begin{abstract}
要 約 : 本論文では, 自閉症児の音声言語獲得の基盤となる前言語的伝達行動（共同注視, 叙述的指さし，リファレンシャル・ルッキング）が成立するための条件を，「環境の中にある刺 激」,「大人」,「子ども」の 3 項関係の中で明らかにし, それを確立するための心理学的指導技 法について検討を加えた. まず, 自閉症児の対人的相互作用, 意志伝達の困難の基礎にある知 覚・認知系の障害を検討した。その結果，重度自閉症児に，さまざまな伝達機能を形成する場 合，(1)社会的刺激に対する視覚的注意を高めるための訓練，(2)特定の方向に注意を定位するた めの腕や指の運動反応形成訓練, (3)大人の視線の動きや, 自分自身の視線の動きと指さしなど の運動反応を協応させるための訓練, (4)外界からの社会的フィードバックに対する応答性を高 める訓練が有効であることが明らかになった。
\end{abstract}

索引用語 : 自閉症児, 前言語的伝達行動, 言語獲得, 認知発達, 社会的交互作用, 行動的援助

\section{Preverbal Communicative Behavior in Children with Autistic Disorders}

\author{
Jun'ichi Yamamoto
}

\begin{abstract}
The purpose of this paper is to examine the conditions of preverbal behavior (joint visual attention, declarative pointing, referential looking) which are necessary to form the basis of language acquisition in children with autistic disorders. Autistic children suffer from qualitative deficits in social interactions and language skills, and have extremely restricted behavior patterns. The basis of these deficits might be caused by perceptual and cognitive characteristics of child-environment interactions. Preverbal bahavior was analyzed in the context of a three-term relationship among child, adult and object, and psychological and behavioral intervention was applied. Three examinations showed the efficacy of the following training for establishing preverbal behavior in children with autistic disorders : (1) training to enhance visual attention to social cues ; (2) training at orienting a target object using eye movement, head turning, and arm and finger movement ; (3) training for coordinating the child's eye movement with arm and finger movement ; (4) training to establish responsiveness to social feedback from adults.
\end{abstract}

Key words : children with autistic disorders, preverbal behavior, language acquisition, cognitive development, social interaction, behavioral intervention

明星大学心理学研究室 : $₹ 191$ 東京都日野市程久保 2-1-1

Department of Psychology, Meisei University : 2-1-1 Hodokubo, Hino-shi, Tokyo 191

原稿受理：1997 年 4 月 22 日 


\section{はじめに}

\section{1. 心理学的観点からの分析}

自閉症児の言語指導において, 音声言語の獲得が目 的とされる場合でも，人に伝達するという言語の機能 的側面を考えると, その前提として次のような心理学 的観点からの指導方法の体系化が必要とされよう. (1) 共時的観点からは, 知覚・認知機構, 動機づけ, 情動 などの自閉症児特有の行動のさまざまな側面と言語と の相互連関, (2)通時的観点からは, 認知発達と言語と の関連.

自閉症児の言語形成のためのプログラムは, 特に発 達心理学, 行動心理学の観点から研究され, 技法の体 系化がなされてきた。発達心理学は, 健常児と自閉症 児との認知・言語の発達の違い, 言語獲得の前提とな る心理学的メカニズムを分析してきた. また行動心理 学と, その臨床への応用である応用行動分析 (Applied Behavior Analysis） は，どのような訓練・指導技法が 自閉症児の全体的発達にとって有効であるかを明らか にしてきた（山本・加藤，1997） ${ }^{1)}$.

本論文では, 自閉症児の音声言語獲得の前提となる 前言語的伝達行動の心理学的指導技法について, 以下 のような順で検討を進める. (1)心理学的, 精神医学的 基準からみた自閉性障害, (2)健常児と自閉症児の認 知・言語発達の差異, (3)れわれが行ってきた言語獲 得の基礎となる前言語的伝達機能の成立条件に関する 実験的研究, (3)応用行動分析の指導技法.

\section{2. 自閉性障害の診断}

アメリカ精神医学会による, 精神疾患の分類基準で ある DSM-IV (diagnostic and statistical manual of mental disorders-fourth edition) においては, 自閉 性障害は, 広汎性発達障害のひとつとして位置づけら れている.この場合の広汎性とは, 学習障害にみられ るような特定的な行動の障害（読字障害, 算数障害, 書字表出障害) ではなく, またコミュニケーション障 害にみられるような言語に特定される障害（表出言語 障害, 受容表出混合性言語障害, 音韻障害)でもなく, 言語, 認知, 社会性, 動機づけなどの広い範囲での障 害が示されることを意味している.DSM-IVでは, 自閉 性障害の診断は, 以下の 3 つの基準によってなされる. (a)対人的相互作用における質的障害：アイコンタクト や身振りなどの対人相互作用を調整するさまざまな非 言語的行動の欠如, 仲間関係の欠如, 楽しみを他人と 共有することの欠如，などが含まれる．言語の前提と なる全体的な伝達行動の欠如である.(b)意志伝達の質 的障害：話し言葉の発達の遅れ，常同的な言語の使用，



\section{共同注祝 (Joint Visual Attention) \\ 指さし (Pointing) \\ 参照的注視 (Referential Looking) 要求的機能 (Mand, Proto-imperative) 叙述的機能 (Tact, Proto-declarative)}

図 1 前言語的伝達行動

ごっこ遊びの欠如，などが含まれる．音声言語の表出 と理解の困難である. (c)行動, 興味が, 限定的, 反復 的，常同的であること．ここには，ひとつの物や行動 への熱中やこだわり，自己刺激行動の頻発，注意が極 端に限定されること，などが含まれる。

\section{3. 前言語的伝達行動の分析}

伝達行動獲得のプロセスは, 母子関係を含めた発達 の中でより詳細に分析すると,「環境の中にある刺激」, 「大人」,「子ども」の 3 項関係の中でとらえられる（図 1). (1)共同注視 (joint visual attention) : 共同注視 とは，大人が外界の特定の物を凝視した場合に，子ど もも大人の視線を追ってそれを凝視する行動をいう. (2)指さし (pointing)の理解：その際，大人の指さしに よって, みる方向が正確になる。 (3)指さしの表出：自 分で指さしを行うことで, 視線の方向と指さしの方向 を協応させると同時に,大人の注意を対象物にむける. 音声表出がともなう場合がある. (4)リファレンシャ ル・ルッキング (referential looking) : 刺激をみた後, 大人の方を向くことで大人もその刺激をみていること を確認する。また，大人の注意を対象物に引きつけ， そのことで対象物の情報を大人と共有する. (5)言語獲 得：対象物と大人の言語反応との間の連合を獲得して ゆく，自閉症児では，これらのプロセスの獲得が困難 であるとされてきた。 


\section{共同注視の困難と高の指導技法}

\section{1 、自閉症児の共同注視の困難さ}

共同注視は, 音声言語の「理解」という観点からみ ると，大人が関心を示しながらみている外界の対象物 を子どももみることで，対象物（視覚刺激）と大人の 言葉かけ（音声刺激）との対応を獲得していくプロセ スの基礎となる，通常の発達では, 対象物が子どもの 視野にある場合には生後 6 力月，それが視野にない場 合には生後 18 力までに共同注視が成立する (Butterworth \& Jarret，1991） ${ }^{2)}$. 子どもが，大人の 指示した視野にない物をみることができるのは，知覚 機能から離れた表象機能の発達を示している。一方, 自閉症児では共同注視が成立しないという報告が数多 くなされている（たとえば, Kasari, Sigman, Mundy, \& Yirmiya，1990) ${ }^{3)}$.これは，これまでは，自閉症児 が相手の意図を理解するといった社会的関係の表象能 力の欠如に関する 1 次的な障害としてとらえられてき た。しかしながら，われわれは，前言語機能の獲得可 能性という観点から，共同注視の欠如は，他者の意図 の理解困難の問題ではなく, 自閉症児の社会的刺激へ の注意の困難，興味関心の限定性，相手の視線に対す る回避傾向, などの知覚・運動系の障害を基礎とした 2 次的な問題であることを実証してきた。以下にその 研究を紹介する（山本，1996） ${ }^{4}$.

\section{2. 共同注視の成立条件（実験 I )}

1) 方法

(1)対象児：無発語の重度自閉症児 2 名（生活年齢は $\mathrm{A}$ 児 5 歳 0 力月, $\mathrm{B}$ 児は 6 歳 4 力月. 発達年齢は $\mathrm{A}$ 児, B 児とも 1 歳 9 力月). 2 名とも強い緊張を含む発声は あるが，言語としては機能化していなかった。また， $\mathrm{A}$ 児はハンドフラッピングなどの自己刺激行動， B 児 は頭を吒くなどの自傷行動が頻発していた。

(2)場面設定：訓練者は，自閉症児と目の高さが同じ になるよう対面して座った.自閉症児の周囲 60 度ごと に，自閉症児の好む絵（乗り物，菓子などの写真）を 配置した（図 2 ).

(3)アイコンタクト訓練期：各試行において，訓練者 は自閉症児と十分にアイコンタクトをとり，6枚の絵 のうちいずれか 1 枚をみた。自閉症児が，訓練者の視 線に対応する絵をみた（共同注視）か，それを指さし たかが記録された。訓練者は 10 秒間刺激をみた後，く すぐりや握手を行うことで，自閉症児との社会的接触 をはかった。

(4)指さし訓練期：視線を向けた絵と指さした絵が一 致しなかった場合には，自閉症児の腕を軽くもって当

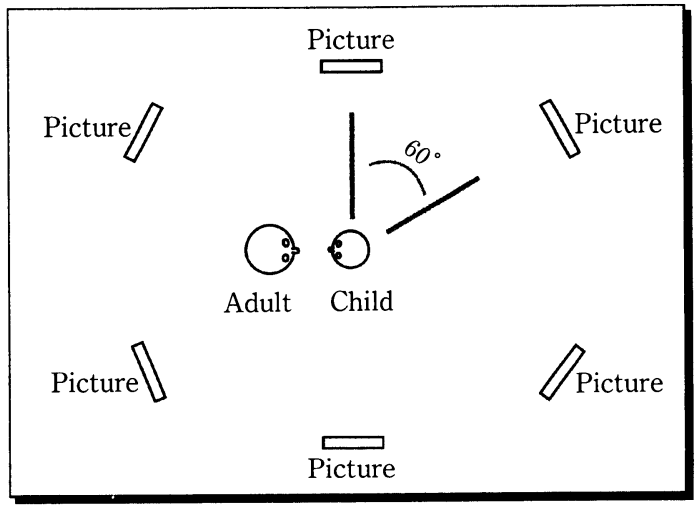

図 2 共同注視実験の場面設定

該の絵を指さすようにし(身体的プロンプト法), 訓練 者が当該の絵を何回もみることにより視線を修正させ る (モデリング法, プロンプト・フェイディング法) ことで, 視線の方向と指さしの方向を一致させる訓練 を行った，自閉症児が視線を向けた絵と指さした絵が 一致した場合には，うなずき，握手，〈すぐり，言語 的応答などのポジティブなフィードバックを与えた。

2 ) 結果と考察

上記の訓練の結果, 無発語の重度自閉症児において も，自分の視野の後方についても相対的に高い割合で 共同注視が成立した (A 児が $75 \%$ ，B児が $63 \%) 。 ま$ た，視線と指さしの方向とを一致させる訓練を行った 結果, 共同注視において視線と適切な指さしの協応 (A 児が $81 \% ，$ B児が $94 \%$ ）が確立された。

これらの結果は, (1)アイコンタクトの訓練などによ って，大人の視線という社会的刺激に対する自閉症児 の注意を十分高めるようにする，(2)自閉症児が興味を もつ刺激を使用することで，みること自体がポジティ ブなフィードバックとなるようにする，(3)視覚・運動 協応を確立しておく，などの技法が自閉症児の前言語 的伝達機能を確立する上で有効であったことを示して いる.

3。文脈刺激の効果の検討（実験 II）

1) 目的

健常児の場合は，大人の視線そのものが，そちらの 方向に面白い物があるということを示す文脈刺激とし て働き，その方向を向くという共同注視反応を生み出 すが，自閉症児の場合は，そのような文脈そのものの 理解が困難であることが共同注視の未成立の原因であ ると考えられる。したがって，文脈を明確にする環境 設定によって自閉症児でも共同注視が確立されるかを 検討した (山本，1996）年。 
2) 方法

(1)対象児：無発語自閉症児 3 名（生活年齢のレンジ は 5 歳 4 カ月から 6 歳 9 力月. 発達年齢のレンジは 1 歳 5 力月から 2 歳 4 力月).

(2)文脈刺激なし条件：実験 I のアイコンタクト訓練 期と同じ場面, 同じ手続きで実施された.

(3)文脈刺激つき条件：自閉症児の好む絵のかわり に, 6 名の大人が 60 度ごとに, 目を閉じて (訓練者の 視線および指さし以外の手がかりを自閉症児に与えな いため）座った。各試行では，まず，訓練者は自閉症 児と十分にアイコンタクトをとり, その後, おもちゃ (ヌイグルミ，ミニカー, 食べ物のミニチャアなど)を 1 個手渡し,「このおもちゃを, あの先生に渡してきて」 といいながら， 6 名の大人のいずれか 1 名をみた。自 閉症児がいずれか 1 名の大人に近づき接触したところ で，その大人におもちゃを受け取るように指示した。 大人におもちゃを手渡した自閉症児が最初の位置に戻 ってきたところで, 訓練者はくすぐりや握手などの社 会的接触を行った.

3 ) 結果と考察

適切に対象者（まわりの大人）をみて，その人にお もちゃを手渡した割合の平均值は, (1)文脈なし条件で, C児 $33 \% ， \mathrm{D}$ 児 $30 \% ， \mathrm{E}$ 児 $57 \%$ ，2文脈つき条件で， C児 $74 \% ， \mathrm{D}$ 児 $77 \% ， \mathrm{E}$ 児 $98 \%$ であった. 全ての自 閉症児が，文脈なし条件に比べ，文脈つき条件で非常 に高い正反応率を示した。

実験 II は, 実験 I とは異なり知覚運動協応を促す直 接的な訓練を行うのではなく, 自閉症児にとって理解 可能な非言語的な文脈刺激を導入したところ，3 名の 自閉症児すべてにおいて, 文脈のある条件下で共同注 視の正反応率が著しく増加した。この結果から, 自閉 症児が既に獲得している行動レパートリー(物を渡す) を利用し, 無発語自閉症児においても理解可能な文脈 を設定したことが，共同注視の獲得に効果をもつこと が明らかになった。

\section{叙述的伝達行動の困難と先の指導技法}

\section{1. リファレンシャル・ルッキング行動と 叙述的伝達行動}

自閉症児の場合, 自分の欲しいものに対して相手の 腕をひっぱって誘導するクレーン反応などの要求的伝 達行動は出現する. ただし, 興味のある物の情報を相 手と共有し, それを伝達することのみを目的とした叙 述的伝達行動の出現はみられないといわれてきている (Baron-Cohen, 19915) : Wetherby \& Prutting, $\left.1984^{6)}\right)$. 音声言語以外の手段で相手に情報を伝達する
ためには, 自分の興味のある対象物をみた後すぐに大 人の方をみたり，大人の方をみながら対象物を指さす ことで大人の注意を引く必要がある。このように，外 界の対象物に大人の注意を引きつける行動はリファレ ンシャル・ルッキング (参照的注視) とよばれている.

リファレンシャル・ルッキングの成立には，次のよ うな行動の確立が前提となる. (1)対象物への定位：自 分の興味のある対象物をみる。(2)相手の顔への定位： 大人の顔を見る. (3)対象物と相手の顔への定位の繰り 返し：対象物と相手の顔を交互にみる。ただし, リフ アレンシャル・ルッキングを含む叙述的伝達行動の訓 練技法（刨田・山本，1991） ${ }^{7)}$ は分に確立されていな い.ここでは, 無発語自閉症児の叙述的伝達行動の獲 得可能性についての実験的研究を紹介する（角谷・山 本, 1997) ${ }^{8)}$.

\section{2. リファレンシャル・ルッキングの成立条件}

1) 方法

(1)対象児：無発語自閉症児 3 名（生活年齢のレンジ は 5 歳 4 カ月から 6 歳 9 カ月, 発達年齢のレンジは 1 歳 5 力月から 2 歳 4 力月).

(2)刺激：自閉症児が興味をもつ，動きのある，音が 出る, あるいは光るおもちゃ(風船, 手袋をはめた手, 太鼓, 懐中電灯, など). 刺激は各試行ごとに変えられ た。

(3)場面：自閉症児は訓練者と目の高さが同じになる ようにイスに着席した。 その正面 $1 \mathrm{~m}$ の距離に小空が 設置され,カーテンを開けることで刺激が提示された。 自閉症児の隣に訓練者が座った。 2 名の観察者が，正 面の衝立の左右に 1 力所ずつ作られた観察用の穴か

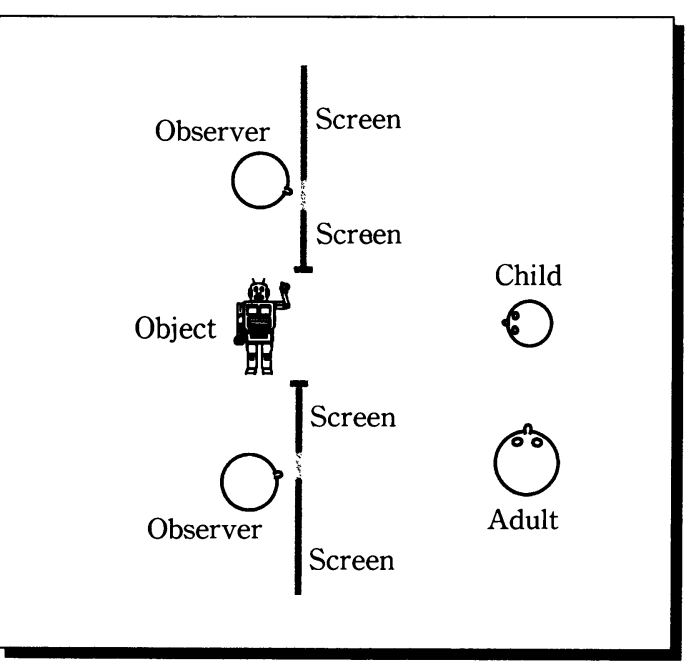

図 3 リファレンシャル・ルッキング実験の場面設定 
ら，自閉症児の視線の動きおよび指さしの生起を記録 した（図 3 ).

(4)手続き：各試行は, 刺激を 1 個小空から提示する ところから開始された。自閉症児が，(1)刺激をみて， (2)訓練者の方を向いて視線を合わせ，(3)再び刺激をみ る, 以上の 3 要素の行動連鎖（刺激と訓練者とを交互 にみる）が生起することがリファレンシャル・ルッキ ングの指標とされた.

(5)ベースライン期：訓練者は，自閉症児の隣に座っ た。自閉症児が刺激を最初にみてから 5 秒以内に, 刺 激と訓練者とを交互にみた場合には，ほほえみ，握手， 言語的賞賛などが与えられた。

(6)訓練期：訓練者は, 自閉症児の正面の刺激の隣に 座った。これは, リファレンシャル・ルッキングの運 動反応の負荷を減らすための場面設定である，自閉症 児が刺激と訓練者とを交互にみる際，ベースライン期 では 90 度の首の運動反応が必要であったが, 訓練期で は約 20 度の首の運動反応で刺激と訓練者とを交互に みることが可能である。訓練者は，自閉症児が刺激を みた直後に，プロンプト(自閉症児の肩をたたく)，モ デリング（訓練者が刺激と自閉症児の顔を交互にみ る), などを与えた.リファレンシャル・ルッキングが 出現した場合には, ほほえみ, 握手, 言語的賞賛が与 えられた。その後, 訓練者は, 徐々に自閉症児の正面 から側方に移動し, 同様の訓練を繰り返した。

(7)プローブ期：ベースライン期と同様の手続きが実 施された。

2 ) 結果と考察

3 名の自閉症児ともリファレンシャル・ルッキング は, ベースライン期では成立しなかった（ $4 \%, 13 \%$, $25 \%)$ が, 訓練期では高い割合で生起した $(85 \%, 91$ $\%, 78 \%)$.プローブ期では, 3 名中 2 名の自閉症児で, 獲得されたリファレンシャル・ルッキングが高い割合 で維持された $(44 \% ， 75 \% ， 17 \%) .2$ 名においては, 直接的な訓練がなされなかったにもかかわらず刺激や 訓練者への視線をともなう指さしが観察された（図
4 ).

本研究では, 刺激と訓練者とを接近させ双方を交互 にみる, 訓練者が反応のモデルを示す, などの訓練の 効果が示された．また, 訓練者と対象物とを交互にみ る社会的相互作用は, 訓練者からの言語的応答（「そ う! あれ, クルクル駒だよー!」), 非言語的応答（微 笑み，身体接触）などのポジティブなフィードバック によって維持されたと考えられる。

対象物が $1 \mathrm{~m}$ 前というたいへん近い位置にあるにも かかわらず，自閉症児はそれを取ろうとせずに，訓練 者との視線の共有だけで十分満足していた。このこと から, 獲得されたリファレンシャル・ルッキングは, 対象物を要求する行動ではなく, 対象物を叙述し伝達 する機能をもっていたと考えられる。

\section{伝達行動形成のための応用行動分析技法}

大人との社会的相互作用を含む機能的伝達行動を形 成するための技法を以下にまとめる.

\section{1. 先行刺激操作技法}

\section{1) 身体的ガイド法}

大人が子どもの身体（体全体, 腕, 手など）を, 緊 張を弛緩させながら直接手を使って誘導する技法であ る. 共同注視課題で, 適切な方向への指さし行動を形 成する場合, 大人が手を添えてその方向に子どもの腕 を誘導する訓練などである.

2) モデリング法

模倣行動を形成する技法をモデリングという．模做 は, (1)単一動作模倣（自分の目を指さすことを模倣さ せアイコンタクトを形成する), (2)一連の流れをもつ動 作の模做 (対象物と訓練者の目を交互にみる), (3)同時 に複数の要素を含む動作の模倣（対象物を指さしなが ら音声を発する), というステップで訓練を遂行してゆ く.

3 ）プロンプト・フェイディング法

それまで与えられていた手がかり刺激を徐々に減ら していくことで, 子どもの自発的行動を成立させてい



図4 リファレンシャル・ルッキング行動と叙述的指さし行動

（ビデオ映像をそのままトレースして作成した） 
く技法である. 適切な方向への指さし行動を形成する 場合，大人の腕の支え（身体的ガバイド）を少しづつ なくしてゆき, 最終的には, 大人の支えがなくとも適 切な指さしが成立するようにもってゆく. 弱められた 手がかり刺激のことをプロンプトと呼ぶ. プロンプト を弱くしてゆく際, 適切な反応が生起しなかったら, すぐにやや強めのプロンプトを与え, 確実に行動の流 れが遂行されるようにする。

4 ) 時間遅延法

行動の自発的な出現を促進するための技法である. 時間遅延法は，一定時間内（たとえば，5秒）に特定 反応が出現しなかった場合にのみプロンプトやモデリ ングを与える技法である. 先のリファレンシャル・ル ッキング行動を形成した際, 対象物を子どもにみせた 後，プロンプトをすぐ与えるのではなく，5秒間子ど もの行動を観察し， 5 秒以内に大人の方をみなかった 場合にのみ, 子どもの肩をたたくなどのプロンプトを 与えた。このような時間遅延法を用いることで, 自発 的なリファレンシャル・ルッキングを含む叙述的言語 行動を形成することができるようになった。あらかじ め設定された一定時間内に, プロンプトなしで出現し た反応を自発的反応とする。

\section{2. 後続刺激操作技法}

通常, 大人は子どものさまざまな行動の直後にポジ ティブなフィードバックを与えている，たとえば「そ うそう, あれブーブーだよ.」などの言語的応答や, 頭 をなでたりする身体接触刺激, 体をゆするなどの自己 受容刺激などがそれである．自閉症児が，一見すると 大人からのかかわりに関心を示さないのは，ポジティ ブなフィードバックとして働く刺激が極端に限定され ているからである。したがって，まず，自閉症児に特 有の興味のある刺激を用いることが肝要である。本研 究では，その自閉症児が特に興味を示す刺激を用い， 共同注視が生起したらすぐにその子どもにとって最も 効果的なフィードバック（例えば，〈すぐり）を与え ることで，共同注視の形成に成功した。

\section{全体的考察}

本論文では, 自閉症児の伝達行動の獲得の基盤とし て, 共同注視, 指さしの理解と表出, リファレンシャ ル・ルッキングの成立条件を分析した研究を紹介して きた。これまで，自閉症児には，相手の意図を理解す るなどの高次の表象機能に 1 次的障害があるとされて きた。しかしながら, 本研究では, これは, 以下のよ うな, 環境との相互作用およびその前提となる知覚運 動系の障害からくる2 次的な問題であると考え, さま

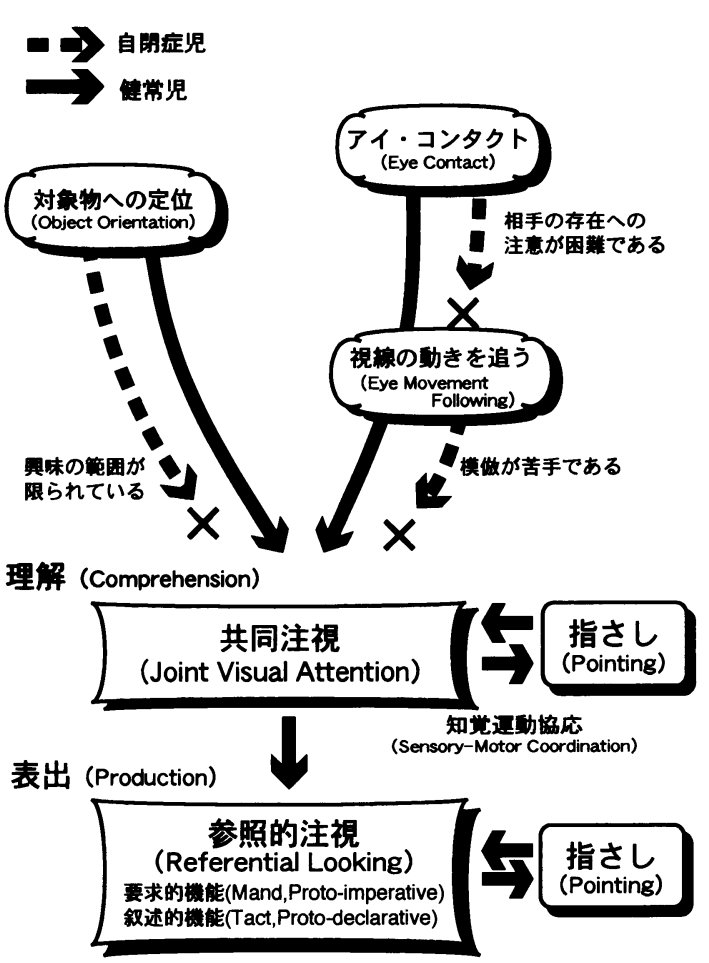

図 5 自閉症児の前言語的伝達行動の阻害要因と その形成過程

ざまな条件のもとで, 前言語的伝達行動の形成のため の条件を明らかにしてきた (図 5 参照)。(1)興味の範囲 が限定されているため対象物に十分な関心を示さなか ったこと，(2)社会的刺激である相手の存在や視線への 注意が困難であること，(3)自己刺激のような内的な感 覚刺激によって外的刺激への注意が遮断化されたこ と，(4)一般的な社会的フィードバックに対する応答性 が少ないこと．このような分析結果にもとづき，重度 自閉症児に, (1)注意機構や視覚野を含む知覚系の機能 化，(2)特定の方向に対する腕や指の運動反応，(3)それ らの間の知覚・運動協応, (4)外界からの社会的フィー ドバックに対する応答性，などを形成することで，さ まざまな伝達機能が確立されることが明らかになっ た.

\section{ま と め}

自閉症児は，大人との相互作用をつくりあげること が困難であるとされてきた．しかしながら，応用行動 分析学の技法を導入することで, 重度自閉症児におい ても，社会的相互作用を含むさまざまな伝達機能が形 成され，言語行動の確立の基礎となることが明らかと 
なった. 知覚, 運動, 認知, 情緒, 動機づけなどさま ざまな点で困難をもつ発達障害児の基礎的な伝達機能 を確立し，それを言語形成につなげていく上で，応用 行動分析学を中心とした心理学的指導技法が, 有効な 手段を提供できょう.この点から, ST と心理学者との 研究上, 技法上の交流が重要なものとなると思われる.

本研究は, 文部省科学研究費補助金・重点領域研究「認知・言 語の成立」(05206108) の補助を受けた。

\section{文献}

1）山本淳一・加藤哲文 編著：障害児者のコミュニケ ーション行動の実現を目指す応用行動分析学入 門. 学苑社, 東京, 1997.

2) Butterworth, G.E., Jarret, N. : What minds have in common is space : spacial mechanisms serving joint visual attention in infancy. British Journal of Developmental Psychology, 9 : 55-72, 1991.

3) Kasari, C., Sigman, N., Mundy, P., Yirmiya, N. : Affective sharing in the context of joint attention interactions of normal, autistic, and mentally retarded children. Journal of Autism and Developmental Disorders, 20 : 87-100, 1990.
4）山本淳一：自閉症児における前言語的行動の成立 条件：共同注視, 指さし, リファレンシャル・ル ッキングの行動分析. 文部省科学研究費補助金重 点領域研究 認知・言語の成立 論文集(2), 41-52. 1996.

5) Baron-Cohen, S. : Precursors to a theory of mind : understanding attention in others. Natural theories of mind. (Edited by Whiten A.) Basil Blackwell, Oxford, pp. 233-251, 1991.

6) Wetherby, A.M., Prutting, C.A. : Profiles of communicative and cognitive-social abilities in autistic children. Journal of Speech and Hearing Research, 27 : 364-377, 1984.

7）刎田文記・山本淳一：発達障害児における “内的” 事象についての報告言語行動（タクト）の獲得と 般化. 行動分析学研究, 6:23-40, 1991.

8）角谷敦子・山本淳一：無発語の自閉症児における 叙述的コミュニケーション行動の成立条件：リフ アレンシャル・ルッキング行動と指さし行動の分 析. 明星大学心理学年報, $15 ： 49-71,1997$.

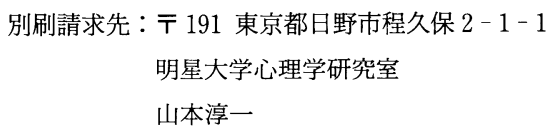

